\title{
Effects of straw retention and phosphorous fertilizer application on available phosphorus content in the soil solution during rice growth
}

\author{
Chao Yan · Houqiang Zhan · Shuangshuang Yan · \\ Shoukun Dong · Chunmei Ma - Qiulai Song • \\ Zhenping Gong $\cdot$ Marcel Barbie
}

Received: 11 October 2014/Revised: 30 December 2014/ Accepted: 10 January 2015/Published online: 21 January 2015 (C) The International Society of Paddy and Water Environment Engineering and Springer Japan 2015

\begin{abstract}
Phosphorus ( $\mathrm{P}$ ) is an essential nutrient for proper rice growth, and available $\mathrm{P}$ in the soil solution is a direct source of $\mathrm{P}$ for rice uptake. In this study, a field experiment (experiment A: straw retention (SRT) treatment versus straw removal (SRM) treatment) exposed to 3 years of continuous SRT and a pot experiment (experiment B: five P levels; SRT and SRM treatments) with different concentrations of applied $\mathrm{P}$ fertilizer were conducted to study the effects of SRT and P fertilizer application on the available $\mathrm{P}$ concentration in the soil solution during rice growth and on rice yield. SRT decreased the available $\mathrm{P}$ concentration in the soil solution, although it did not alter the trend of available $\mathrm{P}$ concentration in the soil solution during plant growth. In addition, in the 10-20-day period after transplantation, the available $\mathrm{P}$ concentration in the soil solution was high, although it decreased thereafter. The available $\mathrm{P}$ concentration in the soil solution increased with the amount of applied $P$ fertilizer, and the rice yield also increased with increasing applications of $\mathrm{P}$ fertilizer. The results of experiments A and B showed that SRT had no significant impact on the rice yield; however, continuous observations over a number of years are required to verify the results.
\end{abstract}

Keywords Rice $\cdot$ Straw retention $\cdot$ Phosphorous fertilizer $\cdot$ Soil solution $\cdot$ Phosphorus

C. Yan - H. Zhan - S. Yan - S. Dong - C. Ma - Q. Song ·

Z. Gong $(\bowtie)$

College of Agriculture, Northeast Agricultural University,

Harbin, Heilongjiang, China

e-mail: gzpyx2004@163.com

M. Barbie

Soil and Water Department, University of Florida, Gainesville, FL, USA

\section{Introduction}

Rice (Oryza sativa L.) is one of the most important crops worldwide, but its production is limited by soil phosphorus (P) deficiencies in many parts of the world (Fageria et al. 2011; Hedley et al. 1994; Raghothama 1999). Phosphorus is a critical nutrient for biological activity (Ramaekers et al. 2010). Inorganic P in soil is the primary source of $P$ for crops (McDowell and Stewart 2006), and the majority of bio-available $\mathrm{P}$ is water-soluble inorganic $\mathrm{P}$ (Toor et al. 2003). Compared with other major nutrients, $P$ is by far the least mobile and least available to plants under most soil conditions (Hinsinger 2001; Schachtman et al. 1998). The orthophosphate taken up by crops originates from the soil solution and solid phase of various inorganic and organic $\mathrm{P}$ fractions (Negassa and Leinweber 2009). The practice of straw retention has been reported to affect available $P$ concentrations in the soil and, consequently, crop yield (Beri et al. 1995; Gupta et al. 2007; Lan et al. 2012; Pathak et al. 2006; Yadvinder et al. 2004). Biological and biochemical reactions, such as mineralization and dissolution by phosphatase enzymes, control much of the organic $\mathrm{P}$ fractions (McGill and Cole 1981; Murrmann and Peech 1969; Medley et al. 1982), and microbial activity has been shown to play a major role in redistributing $\mathrm{P}$ into different forms in the soil. Several studies have demonstrated that multiple years of continuous straw retention reduce the absorption of $\mathrm{P}$ in soil and increase the level of $\mathrm{P}$ released to the surface soil; compared to the practice of straw burning, straw retention increases the available $\mathrm{P}$ content of soil and the crop yield (Pathak et al. 2006). In a northern Indian rice-wheat rotation area, Gupta et al. (2007) observed that after four consecutive years of straw retention, the levels of available $\mathrm{P}$, organic $\mathrm{P}$, and inorganic $\mathrm{P}$ in the soil increased to varying degrees, and continuous straw 
retention provided an equivalent of $13 \mathrm{~kg} \mathrm{ha}^{-1}$ year $^{-1}$ of inorganic P. McLaughlin et al. (1988) found that straw retention in wheat pasture rotations did not have an impact on subsequent crops, although it increased the level of organic P in the soil. Lan et al. (2012) in southern China and Yadvinder et al. (2004) in northern India observed that continuous straw retention coupled with the application of chemical fertilizer increased the content of available $\mathrm{P}$ in the soil. Residues also increase the $\mathrm{P}$ availability in soil by stimulating the microbial production of organic acid anions and phenolic compounds, which might lead to the mobilization of adsorbed $\mathrm{P}$ through competition for $\mathrm{P}$ adsorption sites (Xu et al. 2006). The products of organic residue decomposition can also modify the availability of native soil P (Yadvinder et al. 1992; Nwoke et al. 2004). In waterlogged soils under rice, crop residues can increase the availability of indigenous $\mathrm{P}$ as a result of intense soil reduction (Singh et al. 1988; Yadvinder et al. 2005). Other studies have shown that straw retention has no significant effect on the available P in soil (Malhi et al. 2011; Prasad et al. 1999; Yadvinder et al. 2008). Beri et al. (1995) observed a decrease in the available $\mathrm{P}$ content in soil after 11 consecutive years of straw retention in an Indian ricewheat rotation cropping area. In the same area, Bhandari et al. (2002) reported that the available P in soil decreased significantly after 10 consecutive years of straw retention after the rice season. This might have been caused by the simple crop rotation, which in the long term might have led to reduced yields and less net return of nutrients to the soil as crop residue. However, the disposal of crop residues by burning is often criticized because it accelerates the loss of soil organic matter and nutrients, increases $\mathrm{C}$ emissions, causes intense air pollution, and reduces soil microbial activity (Biederbeck et al. 1980; Kumar and Goh 1999; Rasmussen et al. 1980).

In agricultural production, the nutrient content of the soil solution is an important measurement of soil fertility (Hoagland 1922). $\mathrm{P}$ in the soil solution is a direct source of $\mathrm{P}$ absorbed by crops (Holford 1997). The purpose of this experiment was to study the effects of straw retention on the available $\mathrm{P}$ content in the soil solution and on rice yield. This research will provide a basis for understanding the effects of straw retention on the available $\mathrm{P}$ concentration in soil solutions and determining appropriate fertilizer application levels for rice-growing areas in northeast China.

\section{Materials and methods}

\section{Experimental site}

The study was conducted at XiangFang experimental farm of the Northeast Agricultural University, Harbin $\left(45^{\circ} 34^{\prime}-\right.$ $45^{\circ} 46^{\prime} \mathrm{N}, 126^{\circ} 22^{\prime}-126^{\circ} 50^{\prime} \mathrm{E}, 171.7$ m.a.s.1.), which is located in the state of Heilongjiang, China (Fig. 1). The area receives an average annual rainfall of $500-550 \mathrm{~mm}$, of
Fig. 1 Sketch map showing the locations of the long-term experimental sites in China

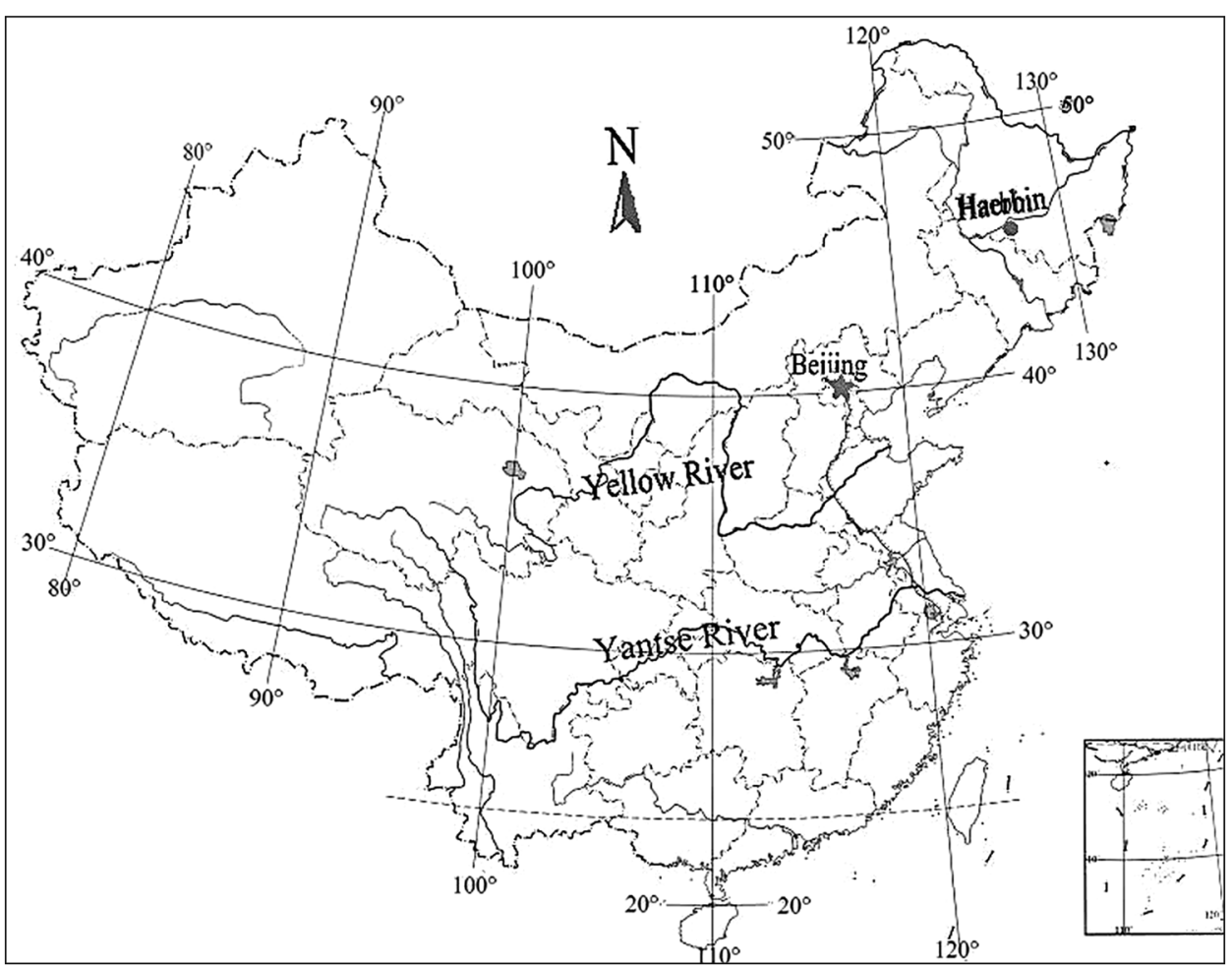


which approximately $80 \%$ occurs between June and September. The region is in a cold temperate climate zone with a continental climate and has a frost-free period of approximately 140 days and a $\geq 10^{\circ} \mathrm{C}$ accumulated temperature of approximately $2,700{ }^{\circ} \mathrm{C}$ per year. There is no crop rotation, the system is composed of continuous rice cropping, and the soil used in the field experimental is Mollisol.

\section{Experimental design}

This work includes three experiments: a field experiment, a pot experiment, and an incubation experiment. The field experiment (experiment A) was conducted from 2008 to 2012, with preliminary experiments conducted in 2008 and 2009. The size of the plots were 2 by $2 \mathrm{~m}$, and they were built using cement and filled with testing soil at a depth of approximately $50 \mathrm{~cm}$. The soil basal fertilities were as follows: $23.92 \mathrm{~g} \mathrm{~kg}^{-1}$ organic matter, $1.48 \mathrm{~g} \mathrm{~kg}^{-1}$ total $\mathrm{N}$, $0.83 \mathrm{~g} \mathrm{~kg}^{-1}$ total $\mathrm{P}, 21.91 \mathrm{~g} \mathrm{~kg}^{-1}$ total $\mathrm{K}, 14.62 \mathrm{mg} \mathrm{kg}^{-1}$ $\mathrm{NH}_{4}{ }^{+}-\mathrm{N}, 30.29 \mathrm{mg} \mathrm{kg}^{-1} \mathrm{NO}_{3}^{-}-\mathrm{N}, 41.95 \mathrm{mg} \mathrm{kg}^{-1}$ Olsen$\mathrm{P}$, and $130.17 \mathrm{mg} \mathrm{kg}^{-1}$ available $\mathrm{K}$. The experimental design was a completely randomized block design with two treatments (straw retention (SRT) and straw removal $(\mathrm{SRM})$ ) and three replicates. The $\mathrm{P}$ content of the straw returned to the soil was $1.80 \pm 0.06 \mathrm{~g} \mathrm{~kg}^{-1}$. The straws were cut into 5 -cm-long pieces, and $5 \mathrm{~kg}\left(12.5 \mathrm{t} \mathrm{ha}^{-1}\right)$ of straw cuttings was embedded in the soil in each plot. Each year, the plots were plowed $(20 \mathrm{~cm})$ on May 20 and then soaked with water on May 25. The seed spacing intra-row was $13 \mathrm{~cm}$ and inter-row was $30 \mathrm{~cm}$, with 3 seedlings per hill. The seedlings were transplanted on May 30. Beginning 10 days after transplanting, samples from the soil solution in the plots were collected once every 10 days. In each plot, $120 \mathrm{~g}$ urea (N $46 \%, 300 \mathrm{~kg} \mathrm{ha}^{-1}$ ), $60 \mathrm{~g}$ $\left(\mathrm{NH}_{4}\right)_{2} \mathrm{HPO}_{4}\left(\mathrm{~N} 18 \%, \mathrm{P}_{2} \mathrm{O}_{5} 46 \%, 150 \mathrm{~kg} \mathrm{ha}^{-1}\right)$, and $40 \mathrm{~g}$ potassium sulfate $\left(\mathrm{K}_{2} \mathrm{O} 30 \%, 100 \mathrm{~kg} \mathrm{ha}^{-1}\right)$ were applied. One half of the urea, $\mathrm{P}$, and potassium were applied as a basal fertilizer, and the other half of the urea was applied at the tillering stage. Prior to transplanting (25-30 May), a water level of 5-7 cm was maintained in the plots. The water level was reduced to $2-3 \mathrm{~cm}$ per week after transplanting and then increased to 5-7 cm from the retention green stage to the milky stage and irrigated to $5 \mathrm{~cm}$ after the water level dried out.

The pot experiment (experiment B) was conducted in 2012. In this experiment, 30-cm-diameter plastic buckets were filled with $15 \mathrm{~kg}$ of soil. To prevent the influence of $\mathrm{P}$ on the basal fertility of the $\mathrm{P}$ fertilizer treatment, a Mollisol with low Olsen-P was used in the experiment. The soil was from a paddy field sowed with rice for multiple consecutive years. The soil's basal fertilities were as follows: $17.42 \mathrm{~g} \mathrm{~kg}^{-1}$ organic matter, $1.53 \mathrm{~g} \mathrm{~kg}^{-1}$ total $\mathrm{N}$,
$0.36 \mathrm{~g} \mathrm{~kg}^{-1}$ total $\mathrm{P}, 25.52 \mathrm{~g} \mathrm{~kg}^{-1}$ total $\mathrm{K}, 10.55 \mathrm{mg} \mathrm{kg}^{-1}$ $\mathrm{NH}_{4}{ }^{-}-\mathrm{N}, 42.63 \mathrm{mg} \mathrm{kg}^{-1} \mathrm{NO}_{3}-\mathrm{N}, 14.97 \mathrm{mg} \mathrm{kg}^{-1}$ Olsen-P, and $137.57 \mathrm{mg} \mathrm{kg}^{-1}$ available $\mathrm{K}$. Three seedlings were planted in each hole, with 3 holes pot $^{-1}$. Five $P$ levels $\left(\mathrm{P}_{0}\right.$, $\mathrm{P}_{1}, \mathrm{P}_{2}, \mathrm{P}_{3}$, and $\mathrm{P}_{4}$ ) were established by applying $0 \mathrm{~g}$ $\left(0 \mathrm{~kg} \mathrm{ha}^{-1}\right), 0.525 \mathrm{~g}\left(75 \mathrm{~kg} \mathrm{ha}^{-1}\right), 1.05 \mathrm{~g}\left(150 \mathrm{~kg} \mathrm{ha}^{-1}\right)$, $1.575 \mathrm{~g}\left(225 \mathrm{~kg} \mathrm{ha}^{-1}\right)$, or $2.1 \mathrm{~g}\left(300 \mathrm{~kg} \mathrm{ha}^{-1}\right) \mathrm{Ca}\left(\mathrm{H}_{2} \mathrm{PO}_{4}\right)_{2}$ $\left(\mathrm{P}_{2} \mathrm{O}_{5}: 61 \%\right)$, respectively, to the five pots. In each pot, $1.05 \mathrm{~g}$ urea $\left(150 \mathrm{~kg} \mathrm{ha}^{-1}\right)$ and $0.70 \mathrm{~g} \mathrm{~K}_{2} \mathrm{SO}_{4}$ $\left(100 \mathrm{~kg} \mathrm{ha}^{-1}\right)$ were also applied as a basal fertilizer, and $1.05 \mathrm{~g}$ urea $\left(150 \mathrm{~kg} \mathrm{ha}^{-1}\right)$ was added at the tillering stage. The experiments were divided into two subgroups: SRT, in which $80 \mathrm{~g}$ straw $\left(12.5 \mathrm{t} \mathrm{ha}^{-1}\right)$ was added, and SRM. Experiment B was replicated five times, and the crop management was the same as in experiment $\mathrm{A}$.

The incubation experiment (experiment C) included two treatments: straw retention (SRT) and straw removal (SRM). In a 500-ml wide-mouthed bottle, $150 \mathrm{~g}$ dry soil (supplemented with $8 \mathrm{~g}$ chopped rice straw [P: $1.82 \pm 0.01 \mathrm{~g} \mathrm{~kg}^{-1}$ ] in the straw retention group) and $250 \mathrm{ml}$ available $\mathrm{P}$ solution were added, and the water line was marked on the bottle. The bottle was then sealed with plastic film and incubated at $25^{\circ} \mathrm{C}$ in an incubator. After each sampling, distilled water was added to compensate for the lost liquid based on the initial marked water line on the bottle. Two subgroups were divided from this group: subgroup I was treated with $5.00 \mathrm{mg} \mathrm{L}^{-1}$ available $\mathrm{P}$ and subgroup II was treated with $10.00 \mathrm{mg} \mathrm{L}^{-1}$ available P. Samples were collected in triplicate at various time points (1d, 5d, 10d, 15d, 20d, 30d, and 40d after inoculation). For sampling, the soil and water were well mixed, the mixture was filtered, and the available P content of the filtrate was determined.

Soil solution collection and analysis

The collection device used to sample the soil solution is shown in Fig. 2. A 30-cm-long hard PVC plastic pipe was sealed at one end, and two holes ( $2 \mathrm{~mm}$ in diameter) were drilled $2-3 \mathrm{~cm}$ from the sealed end as collection apertures for the soil solution. At the other end of the pipe, a vent hole (5 $\mathrm{mm}$ in diameter) was drilled. The collection apertures were wrapped with topical gauze to prevent clogging. Two sampling pipes were placed in each plot, with one pipe for each pot. The pipes were inserted into the soil, so that the collection holes were $10 \mathrm{~cm}$ below the soil surface, and the soil solution was collected from a depth of $10 \mathrm{~cm}$. To ensure that the collected soil solution had infiltrated on the same day, the solution that accumulated during the interval between collections was drained 1 day prior to collection, and the pipe was covered with a rubber stopper to prevent rain and debris from filtering in. During sampling, the soil solutions were transferred to plastic bottles 


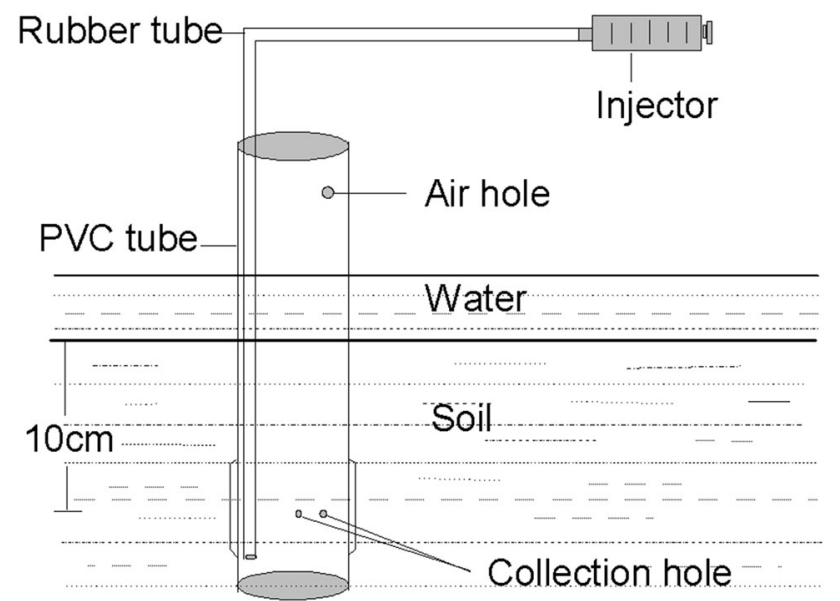

Fig. 2 Soil solution sampling device

and immediately stored in a freezer for subsequent analysis (Diao et al. 2010; Yan et al. 2012).

The available $\mathrm{P}$ in the soil solution was determined according to Watanabe and Olsen (1965). Briefly, the filtrate of the soil solution was added to a developing agent consisting of ammonium molybdate, antimony potassium tartrate, and ascorbic acid, and a colorimetric assay was conducted 30 min later.

Statistical analysis

All P data for the collected soil solutions were subjected to a normality test prior to a one-way analysis of variance (ANOVA) using IBM SPSS Statistics 21.0 (SPSS Inc., Shanghai, China). To compare the treatment mean values,
Duncan's multiple range test was used at a significance level of $P<0.05$. Graphs were produced using Origin 9.0 software.

\section{Results}

Effects of continuous straw retention on the available $\mathrm{P}$ concentration in the soil solution

As shown in Fig. 3, the available $\mathrm{P}$ concentration in the soil solution gradually decreased with rice growth. From 0 to 20 days after transplanting, the available $\mathrm{P}$ concentration in the soil solution was high; the concentration then decreased rapidly, and at 30 days after transplanting, a gradual decrease in the available $\mathrm{P}$ concentration in the soil solution was observed. Compared with 2011 and 2012, the available P concentration in the soil solution decreased more slowly in 2010, but the same trend was observed for all 3 years. The dynamics of the available $\mathrm{P}$ concentration in the soil solution were consistent in both the SRT and SRM treatments during rice growth. However, the level of available $\mathrm{P}$ concentration in the soil solution was lower for the SRT treatment than the SRM treatment. In 2010, 2011, and 2012, the available P concentration in the soil solution of the SRT treatment was lower by $0.086 \pm 0.006 \mathrm{mg} \mathrm{L}^{-1}, 0.022 \pm 0.007 \mathrm{mg} \mathrm{L}^{-1}$, and $0.055 \pm 0.004 \mathrm{mg} \mathrm{L}^{-1}$, respectively, compared with the SRM treatment.

An analysis of the experimental results is shown in Fig. 3, and the regression equations for the duration after transplanting and available $\mathrm{P}$ concentration in the soil solution are shown in Table 1. The results demonstrate that

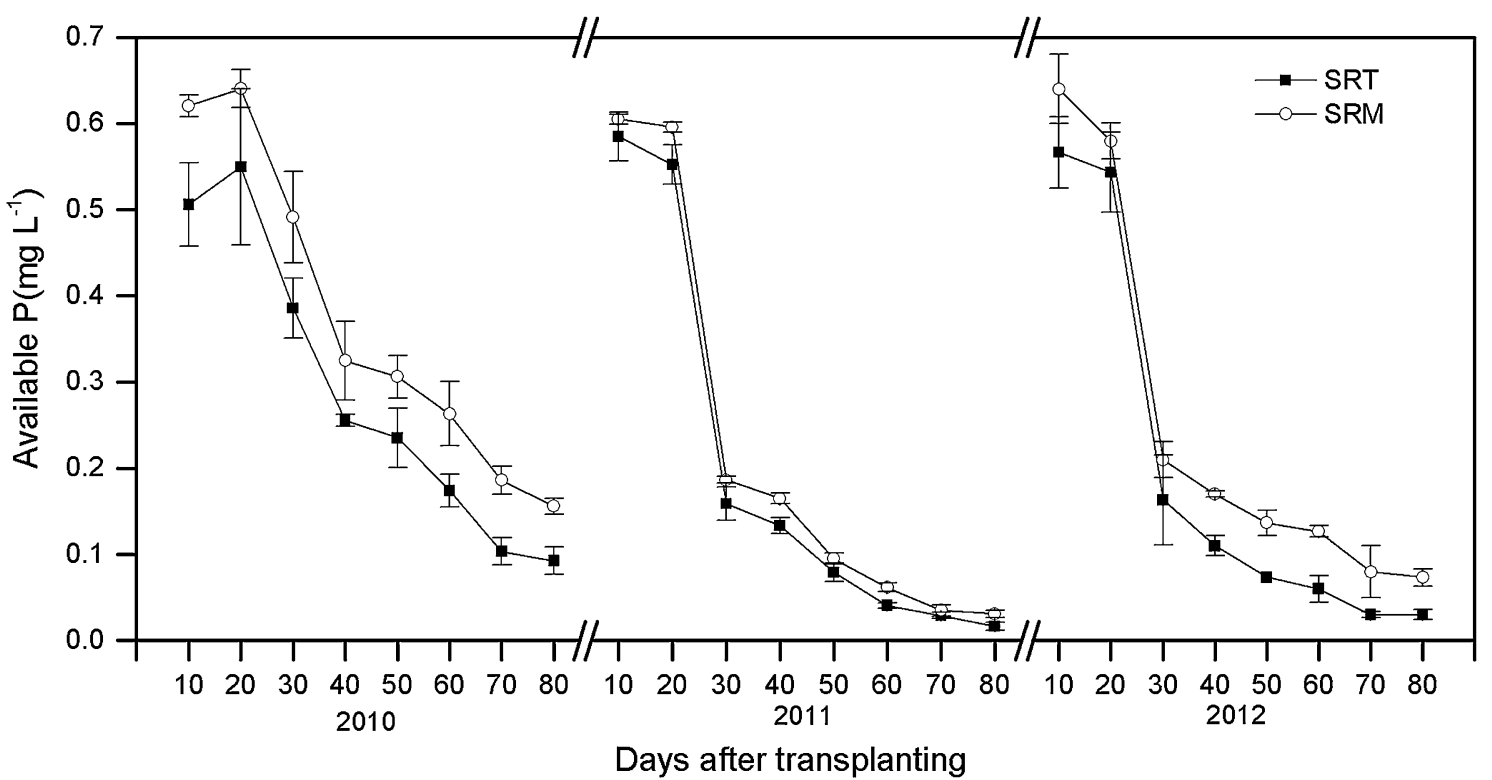

Fig. 3 Changes in the available P concentration in the soil solution. SRT straw retained; SRM straw removed 
Table 1 Relationship between days after transplanting and available $\mathrm{P}$ concentration in soil solution

\begin{tabular}{|c|c|c|c|c|}
\hline \multirow[t]{2}{*}{ Year } & \multicolumn{2}{|l|}{$S R T$} & \multicolumn{2}{|l|}{$S R M$} \\
\hline & Equation & $\mathrm{R}^{2}$ & Equation & $\mathrm{R}^{2}$ \\
\hline 2010 & $y=5.607 x^{-0.869}$ & $0.792 * *$ & $y=4.086 x^{-0.692}$ & $0.828 * * *$ \\
\hline 2011 & $y=60.757 x^{-1.764}$ & $0.888 * * *$ & $y=36.686 x^{-1.560}$ & $0.890 * * *$ \\
\hline 2012 & $\mathrm{y}=33.486 \mathrm{x}^{-1.575}$ & $0.911 * * *$ & $\mathrm{y}=10.771 \mathrm{x}^{-1.121}$ & $0.922 * * *$ \\
\hline
\end{tabular}

SRT straw retained, $S R M$ straw removed, $x$ days after transplanting (day), $y$ available $\mathrm{P}$ concentration in soil solution (mg $\mathrm{L}^{-1}$ )

* $P=0.05$, ** $P=0.01$, *** $P=0.001, n=8$

Table 2 Changes in the available $\mathrm{P}$ in soil solution $\left(\mathrm{mg} \mathrm{L}^{-1}\right)$

\begin{tabular}{lllllllll}
\hline $\begin{array}{l}\text { Incubation } \\
\text { time }\end{array}$ & $1 \mathrm{~d}$ & $5 \mathrm{~d}$ & $10 \mathrm{~d}$ & $15 \mathrm{~d}$ & $20 \mathrm{~d}$ & $30 \mathrm{~d}$ & \\
\hline I & SRM & $1.667 \pm 0.033 \mathrm{~b}$ & $0.280 \pm 0.006 \mathrm{a}$ & $0.095 \pm 0.005 \mathrm{a}$ & $0.073 \pm 0.004 \mathrm{a}$ & $0.060 \pm 0.003 \mathrm{a}$ & $0.043 \pm 0.002 \mathrm{a}$ & $0.040 \pm 0.003 \mathrm{a}$ \\
& SRT & $2.833 \pm 0.083 \mathrm{a}$ & $0.217 \pm 0.007 \mathrm{~b}$ & $0.060 \pm 0.006 \mathrm{~b}$ & $0.042 \pm 0.003 \mathrm{~b}$ & $0.037 \pm 0.003 \mathrm{~b}$ & $0.025 \pm 0.003 \mathrm{~b}$ & $0.022 \pm 0.002 \mathrm{~b}$ \\
& Average & $2.250 \pm 0.264$ & $0.248 \pm 0.015$ & $0.078 \pm 0.009$ & $0.058 \pm 0.008$ & $0.048 \pm 0.006$ & $0.034 \pm 0.004$ & $0.031 \pm 0.004$ \\
II & SRM & $2.555 \pm 0.040 \mathrm{~b}$ & $1.912 \pm 0.135 \mathrm{a}$ & $1.253 \pm 0.022 \mathrm{a}$ & $1.055 \pm 0.008 \mathrm{a}$ & $0.767 \pm 0.061 \mathrm{a}$ & $0.614 \pm 0.036 \mathrm{a}$ & $0.446 \pm 0.033 \mathrm{a}$ \\
& SRT & $3.730 \pm 0.247 \mathrm{a}$ & $0.503 \pm 0.035 \mathrm{~b}$ & $0.055 \pm 0.010 \mathrm{~b}$ & $0.023 \pm 0.003 \mathrm{~b}$ & $0.093 \pm 0.038 \mathrm{~b}$ & $0.019 \pm 0.004 \mathrm{~b}$ & $0.084 \pm 0.009 \mathrm{~b}$ \\
& Average & $3.143 \pm 0.286$ & $1.208 \pm 0.321$ & $0.654 \pm 0.268$ & $0.539 \pm 0.231$ & $0.430 \pm 0.154$ & $0.317 \pm 0.134$ & $0.265 \pm 0.082$
\end{tabular}

Variance analysis, difference between $\mathrm{SN}$ and $\mathrm{S}$ in group I and II at the $P<0.05$ level

Group I was soaked in a solution of $5 \mathrm{mg} \mathrm{L}^{-1}$ inorganic $\mathrm{P}$, and group II was soaked in $10 \mathrm{mg} \mathrm{L}^{-1}$ inorganic $\mathrm{P}$

$S R M$ straw removed, SRT Straw returning

the trends of the available $\mathrm{P}$ concentration in the soil solution over time were identical for the SRT and SRM treatments, whereas the available $\mathrm{P}$ concentration in the soil solution for the SRT treatment was lower than that of the SRM treatment.

The results of experiment $C$ (Table 2) showed that when solutions containing $5 \mathrm{mg} \mathrm{L}^{-1}$ or $10 \mathrm{mg} \mathrm{L}^{-1}$ available $\mathrm{P}$ were used to soak the soil for incubation, the available $\mathrm{P}$ levels were reduced to $2.250 \mathrm{mg} \mathrm{L}^{-1}$ and $3.143 \mathrm{mg} \mathrm{L}^{-1}$, respectively, after 1 day of incubation. With prolonged incubation time, the available $\mathrm{P}$ in the solution continued to decrease, and it was significantly higher in the treatment with SRT than that in SRM, indicating that the water-soluble $\mathrm{P}$ in the rice straw was released into the soil solution at the beginning of the trial. After 5 days of incubation, the available $\mathrm{P}$ content in the soil solution was significantly lower in the SRT than in the SRM treatment. This trend occurred in both of the indoor simulation experiments, which illustrated that straw retention strengthened the soil's absorption capability for available $\mathrm{P}$ in the soil solution.

Effects of the application of fertilizer on the available $\mathrm{P}$ concentration in soil solution

The change in the available $\mathrm{P}$ concentration in soil solution under different levels of $\mathrm{P}$ application during rice growth is shown in Fig. 4. The available P concentration in the soil solution for the SRT and SRM treatments increased with increasing levels of $\mathrm{P}$ fertilizer application. The $\mathrm{P}$ fertilizer application increased the available $\mathrm{P}$ concentration in the soil solution during early rice growth, but it had little effect on the later growth stages (50 days after transplanting). The changes in the available $\mathrm{P}$ concentration in the soil solution followed the same trend as in experiment $\mathrm{A}$.

Experiment B (Fig. 4) also revealed that under different applications of $\mathrm{P}$ fertilizer, the available $\mathrm{P}$ concentration in the soil solution was lower for the SRT treatment than for the SRM treatment. At the $\mathrm{P}_{0}, \mathrm{P}_{1}, \mathrm{P}_{2}, \mathrm{P}_{3}$, and $\mathrm{P}_{4}$ levels, the available $\mathrm{P}$ concentrations in the soil solution for the SRT treatment were lower by $0.010 \pm 0.004 \mathrm{mg} \mathrm{L}^{-1}, 0.005 \pm$ $0.002 \mathrm{mg} \mathrm{L}^{-1}, \quad 0.009 \pm 0.003 \mathrm{mg} \mathrm{L}^{-1}, \quad 0.015 \pm 0.005$ $\mathrm{mg} \mathrm{L}^{-1}$, and $0.009 \pm 0.002 \mathrm{mg} \mathrm{L}^{-1}$, respectively, compared with the SRM treatment, indicating that the amount of available $\mathrm{P}$ in the soil solution decreased with SRT treatment. The available $\mathrm{P}$ concentration in the soil solution gradually decreased with rice growth. However, the trend did not change with the different amounts of $\mathrm{P}$ application.

For experiment $\mathrm{B}$, the regression equation for the amount of applied $\mathrm{P}$ fertilizer and available $\mathrm{P}$ content in the soil solution is shown in Table 3. The available $\mathrm{P}$ concentration in the soil solution was positively correlated with the amount of applied $\mathrm{P}$ fertilizer. The regression equation is adequate for 10 days (June 10) and 40 days 


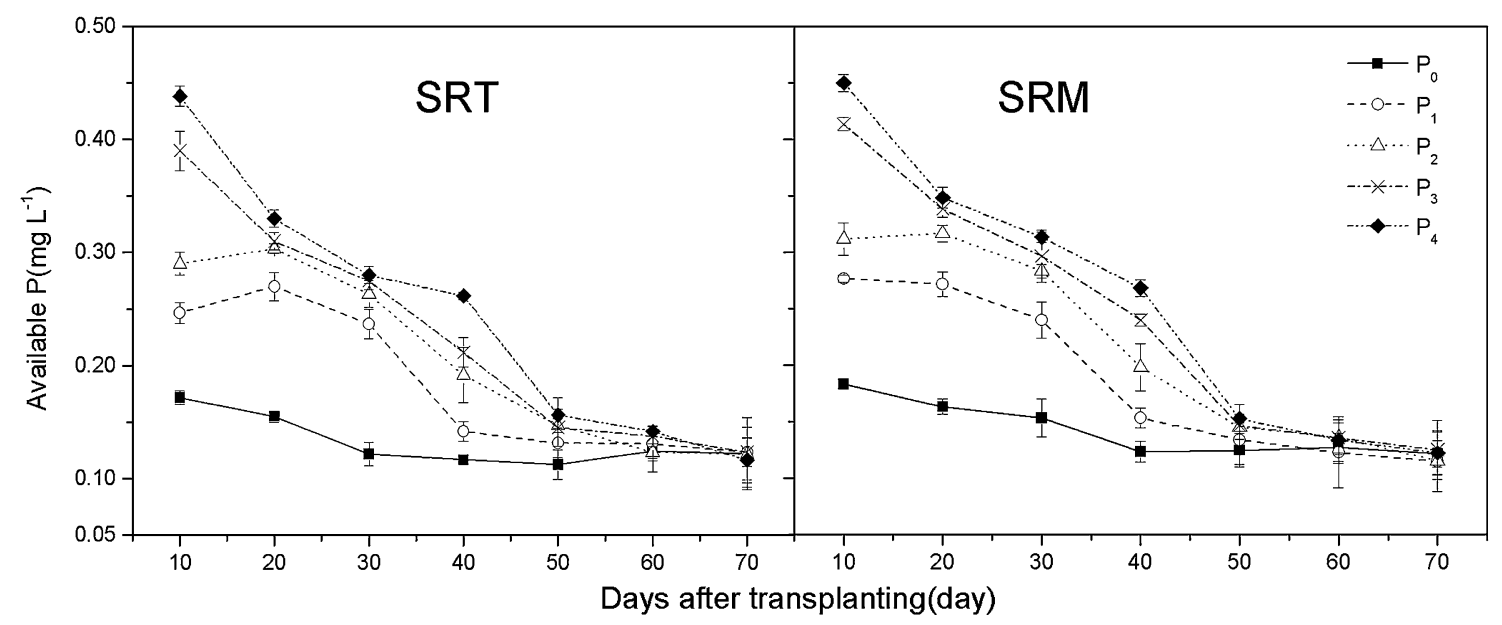

Fig. 4 Changes in the available $\mathrm{P}$ content in the soil solution. $S R T$ straw retained, $S R M$ straw removed. $\left.P_{0} 0 \mathrm{~kg} \mathrm{ha}^{-1} \mathrm{Ca}_{(\mathrm{H}} \mathrm{H}_{2} \mathrm{PO}_{4}\right)_{2}, P_{1}$ $75 \mathrm{~kg} \mathrm{ha}^{-1} \mathrm{Ca}\left(\mathrm{H}_{2} \mathrm{PO}_{4}\right)_{2}, P_{2} 150 \mathrm{~kg} \mathrm{ha}^{-1} \mathrm{Ca}\left(\mathrm{H}_{2} \mathrm{PO}_{4}\right)_{2}, P_{3} 225 \mathrm{~kg} \mathrm{ha}^{-1} \mathrm{Ca}\left(\mathrm{H}_{2} \mathrm{PO}_{4}\right)_{2}$, and $P_{4} 300 \mathrm{~kg} \mathrm{ha}^{-1} \mathrm{Ca}\left(\mathrm{H}_{2} \mathrm{PO}_{4}\right)_{2}$

Table 3 Relationship between $P$ fertilizer applied and available $\mathrm{P}$ concentration in solution

$S R T$ straw retained, SRM straw removed, $x$ Phosphorus fertilizer application rate $\left(\mathrm{kg} \mathrm{ha}^{-1}\right), y \mathrm{P}$ concentration in soil solution $\left(\mathrm{mg} \mathrm{L}^{-1}\right)$

$* P=0.05, * * P=0.01$,

*** $P=0.001, n=5$

\begin{tabular}{llllll}
\hline Days & \multicolumn{2}{l}{$S R T$} & & \multicolumn{2}{l}{$S R M$} \\
\cline { 2 - 3 } \cline { 5 - 6 } & Equation & $\mathrm{R}^{2}$ & & Equation & $\mathrm{R}^{2}$ \\
\hline 10 & $\mathrm{y}=0.0009 \mathrm{x}+0.1720$ & $0.9829 * * *$ & & $\mathrm{y}=0.0009 \mathrm{x}+0.1930$ & $0.9681^{* *}$ \\
20 & $\mathrm{y}=0.0005 \mathrm{x}+0.1957$ & $0.7084^{*}$ & & $\mathrm{y}=0.0006 \mathrm{x}+0.2003$ & $0.7812^{*}$ \\
30 & $\mathrm{y}=0.0005 \mathrm{x}+0.1644$ & 0.6394 & & $\mathrm{y}=0.0005 \mathrm{x}+0.1820$ & $0.8148^{*}$ \\
40 & $\mathrm{y}=0.0005 \mathrm{x}+0.1127$ & $0.9777^{* * *}$ & & $\mathrm{y}=0.0005 \mathrm{x}+0.1213$ & $0.9921^{* * *}$ \\
50 & $\mathrm{y}=0.0001 \mathrm{x}+0.1182$ & $0.8470^{*}$ & & $\mathrm{y}=0.0001 \mathrm{x}+0.1269$ & $0.9310^{* *}$ \\
60 & $\mathrm{y}=0.0001 \mathrm{x}+0.1233$ & 0.5470 & & $\mathrm{y}=0.0000 \mathrm{x}+0.1259$ & 0.3251 \\
70 & $\mathrm{y}=0.0000 \mathrm{x}+0.1239$ & 0.2312 & & $\mathrm{y}=0.0000 \mathrm{x}+0.1174$ & -0.1081 \\
\hline
\end{tabular}

Table 4 Effect of rice straw amendment on yield of rice $\left(\mathrm{kg} \mathrm{m}^{-2}\right)$

\begin{tabular}{lllll}
\hline Incubation time & 2010 & 2011 & 2012 & Average \\
\hline SRT & $0.8725 \pm 0.0200 \mathrm{a}$ & $0.8975 \pm 0.0725 \mathrm{a}$ & $0.8800 \pm 0.0100 \mathrm{a}$ & $0.8825 \pm 0.0075 \mathrm{a}$ \\
SRM & $0.8025 \pm 0.0700 \mathrm{a}$ & $0.8375 \pm 0.0950 \mathrm{a}$ & $0.8050 \pm 0.0175 \mathrm{~b}$ & $0.8150 \pm 0.0125 \mathrm{~b}$ \\
\hline
\end{tabular}

$S R T$ straw retained, $S R M$ straw removed

$* P=0.05$

(July 10) after transplanting. As shown in Table 2, the P fertilizer obviously affected the available $\mathrm{P}$ concentration in the soil solution 10 days after transplanting, and this effect decreased with time.

Based on the one-dimensional linear regression equation of the available $\mathrm{P}$ concentration in the soil solution and the $\mathrm{P}$ application amount, the level of available $\mathrm{P}$ in the soil solution decreased by $0.021 \mathrm{mg} \mathrm{L}^{-1}$ on average as a result of the SRT treatment. This decline corresponds to $23.33 \mathrm{~kg} \mathrm{ha}^{-1} \mathrm{Ca}\left(\mathrm{H}_{2} \mathrm{PO}_{4}\right)_{2}$, which is equivalent to $6.21 \mathrm{~kg} \mathrm{ha}^{-1} \mathrm{P}$. This amount of $\mathrm{P}$ had to be applied to compensate for the loss of available $\mathrm{P}$ resulting from the SRT treatment and achieve the same level of available $\mathrm{P}$ content in the soil solution and rice yield as the SRM treatment.

Effect of straw retention and $\mathrm{P}$ application rate on rice yield

The rice yield from experiment $\mathrm{A}$ is shown in Table 4. The rice yield was higher for the SRT treatment than for the SRM treatment, and the average yield in 2012 differed from the yields in 2010 and 2011. Table 5 shows the trend of the rice yield in experiment B; the rice yield in the SRT and SRM treatments increased with increasing amounts of applied P fertilizer. The rice yield was significantly lower 
Table 5 Rice yield and phosphorous fertilizer application $\left(\mathrm{g} \mathrm{pot}^{-1}\right)$

\begin{tabular}{llllll}
\hline Incubation time & $P_{0}$ & $P_{1}$ & $P_{2}$ & $P_{3}$ & $P_{4}$ \\
\hline SRT & $100.95 \pm 1.54 \mathrm{~b}$ & $110.47 \pm 0.15 \mathrm{~b}$ & $121.78 \pm 2.45 \mathrm{a}$ & $129.48 \pm 2.97 \mathrm{a}$ & $136.86 \pm 8.40 \mathrm{a}$ \\
SRM & $110.38 \pm 0.94 \mathrm{a}$ & $119.52 \pm 0.17 \mathrm{a}$ & $118.08 \pm 0.78 \mathrm{a}$ & $124.54 \pm 5.10 \mathrm{a}$ & $129.36 \pm 2.59 \mathrm{a}$ \\
\hline
\end{tabular}

$S R T$ straw retained, $S R M$ straw removed

* $P=0.05$

for the SRT treatment than for the SRM treatment at low levels of $\mathrm{P}\left(\mathrm{P}_{0}\right.$ and $\left.\mathrm{P}_{1}\right)$. The yield was slightly higher for the SRT treatment than for the SRM treatment at the $\mathrm{P}_{2}, \mathrm{P}_{3}$, and $\mathrm{P}_{4}$ levels, but these differences were not significant. The results demonstrate that straw retention has a negative impact on the rice yield at low levels of P soil fertility, and thus, the amount of $\mathrm{P}$ fertilizer application should be adjusted to ensure rice yield.

\section{Discussion}

Changes in the available $\mathrm{P}$ concentration in the soil solution during rice growth

In the early stages of plant growth, the $\mathrm{P}$ supply is critical for crop production, and a deficiency in the $\mathrm{P}$ supply during the first 4-6 weeks of wheat growth has been found to produce significant decreases in tillering and panicle formation in the plant (Grant et al. 2001). After the application of $\mathrm{P}$ fertilizer to the soil, the phosphate ions in the soil solution are consumed by organisms or adsorbed and immobilized by the soil over time (Miller et al. 2011). The results of experiments A (Fig. 3) and B (Fig. 4) revealed that the available $\mathrm{P}$ concentration in the soil solution was high during the 0- to 20-day period after transplanting but gradually decreased during rice growth, possibly due to the absorption and immobilization of $\mathrm{P}$ by rice in the solid phase in the soil. These dynamic changes in the available $\mathrm{P}$ concentration suggest that $\mathrm{P}$ absorption by rice plants is sufficient during the early growth stages but becomes insufficient during the later stages of growth.

Stevenson and Cole (1999) claimed that straw retention changes the balance of $\mathrm{P}$ in the soil due to straw decomposition and consumption by organisms. The results from experiments A and B indicate that the SRT treatment decreased the available $\mathrm{P}$ concentration in the soil solution, possibly due to microbial fixation of the available $\mathrm{P}$ in the soil solution. The results of Gupta et al. (2007) and Phiri et al. (2001) demonstrated that multiple years of straw retention reduced the soil absorption of $\mathrm{P}$ and increased the release of available $\mathrm{P}$ in the surface soil, respectively. Yadvinder et al. (2010) also reported a gradual decrease in the relative $\mathrm{P}$ content of straw with increasing time after straw retention, indicating a continuous release of $\mathrm{P}$ from the decomposing straw. Both the field planting and the potplanting experiments indicate that most of the $\mathrm{P}$ nutrients released from the decomposed straw were absorbed by the soil solid phase and did not enter the soil solution.

A portion of the $\mathrm{P}$ fertilizer that was applied to the crop was consumed by the plants, and the remainder entered the soil exchange sites and precipitated due to soil adsorption (Muhammad et al. 2013). In experiment B, augmentation with $\mathrm{P}$ fertilizer significantly increased the levels of available $\mathrm{P}$ in the soil solution, but the increment diminished 60 days after transplanting (July 30), indicating that the application of $P$ fertilizer could effectively increase the available $P$ content of the soil solution and could maintain that level for up to 60 days after transplantation (Table 3 ). The availability of $P$ in the soil is a limiting factor in rice production (Dobermann et al. 1998; Pheav et al. 2003). Experiment B demonstrated that the decrease in available $\mathrm{P}$ concentration in the soil solution in the SRM treatment had little impact on the rice yield at high $\mathrm{P}$ levels but did influence the rice yield at low $\mathrm{P}$ levels; therefore, the applied amount of $\mathrm{P}$ fertilizer should be increased when straw is retained.

In the $\mathrm{A}, \mathrm{B}$, and $\mathrm{C}$ experiments, the available $\mathrm{P}$ content in the soil solution for the SRT treatment was lower than that for the SRM treatment; this result was caused by increased levels of carbon sources in the soil related to straw retention, which led to increased microbial biomass and microbial activities that promoted the conversion and retention of inorganic $\mathrm{P}$ in the soil (McLaughlin et al. 1988). Beri et al. (1995) also claimed that when straw with high ratios of $\mathrm{C}: \mathrm{P}$ was mixed with soil, the straw enhanced $\mathrm{P}$ adsorption in the soil within the same growth season (McGill and Cole 1981; Murrmann and Peech 1969; Medley et al. 1982). Microbial activity has been shown to play a major role in redistributing $\mathrm{P}$ into different forms in the soil, and straw retention has been shown to affect the balance of P in the soil (McGill and Cole 1981; Murrmann and Peech 1969).

Effects of straw retention and $\mathrm{P}$ fertilizer application on rice yield

Beckwith (1965) and Fox and Kamprath (1970) determined that a $\mathrm{P}$ concentration of $0.2 \mathrm{mg} \mathrm{L}^{-1}$ in the soil solution 
was sufficient to provide adequate $\mathrm{P}$ for many crops. Mehdi et al. (2007) also observed that when the concentration of $P$ in a soil solution reached $0.252 \mathrm{mg} \mathrm{L}^{-1}$, a rice yield of $95 \%$ was obtained; beyond this concentration, increased $\mathrm{P}$ levels did not affect the yield of the crop, even when $\mathrm{P}$ was increased to $0.50 \mathrm{mg} \mathrm{L}^{-1}$. In experiment $\mathrm{A}$ in this study, the available $\mathrm{P}$ concentration in the soil solution 10-20 days after transplanting was higher than $0.252 \mathrm{mg} \mathrm{L}^{-1}$ for both the treatments. The rice yield was slightly higher in the SRT treatment than in the SRM treatment, and only the yield in 2012 was significantly different among the 3 years of experiments.

At the $\mathrm{P}_{0}$ level in experiment $\mathrm{B}$, the available $\mathrm{P}$ concentration in the soil solution was less than $0.252 \mathrm{mg} \mathrm{L}^{-1}$ (Mehdi et al. 2007) throughout the entire growth stage in both the SRT and SRM treatments. At the $\mathrm{P}_{1}$ level, during the growth period 0-30 days after transplanting, the available $\mathrm{P}$ content in the soil solution was close to the threshold value in both the straw retention and straw removal treatments, whereas the values were higher than the threshold value at the $\mathrm{P}_{2}, \mathrm{P}_{3}$, and $\mathrm{P}_{4}$ levels 30 days after transplanting. The available $\mathrm{P}$ content in the soil solution was higher than the threshold value at 40 days after transplanting only for the $\mathrm{P}_{4}$ level.

At the $\mathrm{P}_{0}$ and $\mathrm{P}_{1}$ levels, the yield was lower in the SRT treatment than in the SRM treatment, and there was no significant difference in rice yield between the treatments at the $\mathrm{P}_{2}, \mathrm{P}_{3}$, and $\mathrm{P}_{4}$ levels. These results demonstrate that the straw retention reduced the available $\mathrm{P}$ in the soil solution in experiments $\mathrm{A}$ and $\mathrm{B}$ at the $\mathrm{P}_{2}, \mathrm{P}_{3}$, and $\mathrm{P}_{4}$ levels, but had no significant influence on the rice yield; thus, additional $\mathrm{P}$ fertilizer was not required. However, straw retention should be accompanied by an increase in $\mathrm{P}$ fertilizer application to achieve good yields at low P levels.

Studies have been conducted to investigate the relationship between straw retention, available $\mathrm{P}$ content in the soil solution and yield (Beri et al. 1995; Gupta et al. 2007; Lan et al. 2012; McLaughlin et al. 1988; Pathak et al. 2006; Yadvinder et al. 2004), and the results showed that straw retention had a significant impact on the available $\mathrm{P}$ content in the soil solution and rice yield, although the results were not consistent. In this study, straw retention had no significant impact on yield; however, the test results should be verified in experiments conducted over longer time periods.

\section{Conclusions}

Straw retention decreased the available $\mathrm{P}$ concentration in the soil solution, although it did not alter the trend of available $\mathrm{P}$ concentration in the soil solution during plant growth. In addition, in the 10-20-day period after transplantation, the available $\mathrm{P}$ concentration in the soil solution was high, although it decreased thereafter. The available $P$ concentration in the soil solution increased with the amount of applied $\mathrm{P}$ fertilizer, and the rice yield also increased with increasing applications of $\mathrm{P}$ fertilizer. The results of experiments $\mathrm{A}$ and $\mathrm{B}$ showed that straw retention had no significant impact on the rice yield; however, years of continuous observation are required to verify these results. In this study, $\mathrm{P}$ (inorganic and organic form) content in the soil did not produce a significant effect on the rice yield. Application of $\mathrm{P}$ may be absorbed by the soil and result in increased $\mathrm{P}$ concentrations in the soil. Therefore, continuous experiments should be conducted at this experimental site to observe the long-term effects.

Acknowledgments We are indebted to the group of researchers who initiated and maintained the rice straw retention experiment at Harbin. This group includes but is not limited to Drs. Zhenping Gong, Chunmei Ma, Shoukun Dong, and Qiulai Song. Dr. Marcel Barbie offered a critical review of the manuscript. Zhenping Gong and Shoukun Dong provided valuable laboratory assistance. The NEAU Graduate School and College of Agriculture provided research support. This study was funded by the China National "Twelfth-FiveYear" Science and Technology Support Program and Program of Integration and Demonstration of Large-Scale Agricultural Technology Circulation in the "Three Rivers Plain" (2012BAD14B06).

\section{References}

Beckwith R (1965) Sorbed phosphate at standard supernatant concentration as an estimate of the phosphate needs of soils. Anim Prod Sci 5:52-58

Beri V, Sidhu B, Bahl G, Bhat A (1995) Nitrogen and phosphorus transformations as affected by crop residue management practices and their influence on crop yield. Soil Use Manag 11:51-54

Bhandari A, Ladha J, Pathak H, Padre A, Dawe D, Gupta R (2002) Yield and soil nutrient changes in a long-term rice-wheat rotation in India. Soil Sci Soc Am J 66:162-170

Biederbeck VO, Campbell CA, Bowren KE, Schnitzer M, McIver RN (1980) Effect of burning cereal straw on soil properties and grain yields in Saskatchewan1. Soil Sci Soc Am J 44:103-111. doi:10. 2136/sssaj1980.03615995004400010022x

Diao XL, Zeng XL, Gong ZP, Ma CM, Zhang L et al (2010) Effect of straw returning on nutrients change in soil solution during rice growth period. J Northeast Agric Univ 182:43-48 (in Chinese)

Dobermann A, Cassman K, Mamaril C, Sheehy J (1998) Management of phosphorus, potassium, and sulfur in intensive, irrigated lowland rice. Field Crops Res 56:113-138

Fageria N, Santos A, Heinemann A (2011) Lowland rice genotypes evaluation for phosphorus use efficiency in tropical lowland. J Plant Nutr 34:1087-1095

Fox RL, Kamprath E (1970) Phosphate sorption isotherms for evaluating the phosphate requirements of soils. Soil Sci Soc Am J 34:902-907

Grant C, Flaten D, Tomasiewicz D, Sheppard S (2001) The importance of early season phosphorus nutrition. Can J Plant Sci 81:211-224

Gupta R, Ladha J, Singh J, Singh G, Pathak H (2007) Yield and phosphorus transformations in a rice-wheat system with crop residue and phosphorus management. Soil Sci Soc Am J 71:1500-1507 
Hedley M, Kirk G, Santos M (1994) Phosphorus efficiency and the forms of soil phosphorus utilized by upland rice cultivars. Plant Soil 158:53-62

Hinsinger P (2001) Bioavailability of soil inorganic P in the rhizosphere as affected by root-induced chemical changes: a review. Plant Soil 237:173-195

Hoagland DR (1922) The soil solution in relation to the plant. Trans Faraday Soc 17:249-255

Holford I (1997) Soil phosphorus: its measurement, and its uptake by plants. Aust J Soil Res 35:227-240

Kumar K, Goh K (1999) Crop residues and management practices: effects on soil quality, soil nitrogen dynamics, crop yield, and nitrogen recovery. Adv Agron 68:197-319

Lan ZM, Lin XJ, Wang F, Zhang H, Chen CR (2012) Phosphorus availability and rice grain yield in a paddy soil in response to long-term fertilization. Biol Fertil Soils 48:579-588

Malhi SS, Nyborg M, Solberg ED, McConkey B, Dyck M, Puurveen $\mathrm{D}$ (2011) Long-term straw management and $\mathrm{N}$ fertilizer rate effects on quantity and quality of organic $\mathrm{C}$ and $\mathrm{N}$ and some chemical properties in two contrasting soils in Western Canada. Biol Fertil Soils 47:785-800

McDowell R, Stewart I (2006) The phosphorus composition of contrasting soils in pastoral, native and forest management in Otago, New Zealand: sequential extraction and 31P NMR. Geoderma 130:176-189

McGill W, Cole C (1981) Comparative aspects of cycling of organic $\mathrm{C}, \mathrm{N}, \mathrm{S}$ and $\mathrm{P}$ through soil organic matter. Geoderma 26:267-286

McLaughlin MJ, Alston A, Martin J (1988) Phosphorus cycling in wheat pasture rotations. I. The source of phosphorus taken up by wheat. Soil Res 26:323-331

Medley MJ, Stewart JWB, Chauhanm BS (1982) Changes in inorganic and organic soil phosphorus fractions induced by cultivation practices and by laboratory incubations. Soil Sci Soc Am J 46:970-976

Mehdi SM, Obaid-ur-Rehman A, Ranjha M, Sarfaraz M (2007) Adsorption capacities and availability of phosphorus in soil solution for rice wheat cropping system. World Appl Sci J 2:244-265

Miller JJ, Chanasyk DS, Curtis TW, Olson BM (2011) Phosphorus and nitrogen in runoff after phosphorus-or nitrogen-based manure applications. J Environ Qual 40:949-958

Muhammad AS, Manaf A, Hussain M, Farooq S, Zafar-ul-Hye M (2013) Sulphur fertilization improves the sesame productivity and economic returns under rainfed conditions. Int J Agric Biol 15(6):1301-1306

Murrmann R, Peech M (1969) Effect of pH on labile and soluble phosphate in soils. Soil Sci Soc Am J 33:205-210

Negassa W, Leinweber P (2009) How does the Hedley sequential phosphorus fractionation reflect impacts of land use and management on soil phosphorus: a review. J Plant Nutr Soil Sci 172:305-325

Nwoke O, Vanlauwe B, Diels J, Sanginga N, Osonubi O (2004) Impact of residue characteristics on phosphorus availability in West African moist savanna soils. Biol Fertil Soils 39:422-428

Pathak H, Singh R, Bhatia A, Jain N (2006) Recycling of rice straw to improve wheat yield and soil fertility and reduce atmospheric pollution. Paddy Water Environ 4:111-117

Pheav S, Bell R, White P, Kirk G (2003) Fate of applied fertilizer phosphorus in a highly weathered sandy soil under lowland rice cropping, and its residual effect. Field Crops Res 81:1-16
Phiri S, Amézquita E, Rao IM, Singh B (2001) Disc harrowing intensity and its impact on soil properties and plant growth of agropastoral systems in the Llanos of Colombia. Soil Tillage Res 62:131-143

Prasad R, Gangaiah B, Aipe K (1999) Effect of crop residue management in a rice-wheat cropping system on growth and yield of crops and on soil fertility. Exp Agric 35:427-435

Raghothama K (1999) Phosphate acquisition. Annu Rev Plant Biol 50:665-693

Ramaekers L, Remans R, Rao IM, Blair MW, Vanderleyden J (2010) Strategies for improving phosphorus acquisition efficiency of crop plants. Field Crops Res 117:169-176

Rasmussen PE, Allmaras RR, Rohde CR, Roager NC (1980) Crop residue influences on soil carbon and nitrogen in a wheat-fallow system1. Soil Sci Soc Am J 44:596-600. doi:10.2136/sssaj1980. $03615995004400030033 x$

Schachtman DP, Reid RJ, Ayling SM (1998) Phosphorus uptake by plants: from soil to cell. Plant Physiol 116:447-453

Singh Y, Singh B, Maskina M, Meelu O (1988) Effect of organic manures, crop residues and green manure (Sesbania aculeata) on nitrogen and phosphorus transformations in a sandy loam at field capacity and under waterlogged conditions. Biol Fertil Soils 6:183-187

Stevenson FJ, Cole MA (1999) Cycles of soils: carbon, nitrogen, phosphorus, sulfur, micronutrients. Wiley, New York

Toor GS, Condron LM, Di HJ, Cameron KC, Cade-Menun BJ (2003) Characterization of organic phosphorus in leachate from a grassland soil. Soil Biol Biochem 35:1317-1323

Watanabe F, Olsen S (1965) Test of an ascorbic acid method for determining phosphorus in water and $\mathrm{NaHCO}_{3}$ extracts from soil. Soil Sci Soc Am J 29:677-678

Xu J, Tang C, Chen ZL (2006) The role of plant residues in $\mathrm{pH}$ change of acid soils differing in initial $\mathrm{pH}$. Soil Biol Biochem 38:709-719

Yadvinder S, Bijay S, Khind CS (1992) Nutrient transformations in soils amended with green manures. Adv Soil Sci 20:237-309

Yadvinder S, Bijay S, Timsina J (2005) Crop residue management for nutrient cycling and improving soil productivity in rice-based cropping systems in the tropics. In: Advances in agronomy, vol 85. Academic Press, pp 269-407. doi:10.1016/S00652113(04)85006-5

Yadvinder S, Gupta RK, Gurpreet S, Jagmohan S, Sidhu HS, Bijay S (2008) Nitrogen and residue management effects on agronomic productivity and nitrogen use efficiency in rice-wheat system in Indian Punjab. Nutr Cycl Agroecosyst 84:141-154

Yadvinder S, Gupta RK, Jagmohan S, Gurpreet S, Gobinder S, Ladha JK (2010) Placement effects on rice residue decomposition and nutrient dynamics on two soil types during wheat cropping in rice-wheat system in northwestern India. Nutr Cycl Agroecosyst $88: 471-480$

Yadvinder S, Bijay S, Ladha JK, Khind CS, Gupta RK, Meelu OP, Pasuquin E (2004) Long-term effects of organic inputs on yield and soil fertility in the rice-wheat rotation. Soil Sci Soc Am J 68:845-853

Yan C, Diao XL, Ge HL, Wang XW, Ma CM et al (2012) Effects of rice straw returning on nutrients in soil solution and activities of soil enzymes. Chin J Soil Sci 260:1232-1236 (in Chinese) 